doi: 10.52370/TISC21232DC

\title{
THE INFLUENCE OF FEARS ON THE TRAVEL DECISION - COVID FEAR AGAINST MONEY FEAR
}

\author{
Drago Cvijanovićl ; Tamara Gajic $^{2}$
}

\begin{abstract}
The American National Institute of Mental Health announced that 10\% of the total adult population has some kind of phobia. With the appearance of the COVID - 19 infection, and the huge consequences it left behind, there is a growing fear of people deciding to travel. There is a growing fear of infection after a year, but also a fear of lack of money, at a time when protection measures have destroyed tourism and hospitality. About 6,000 experts, including many scientists from the UK, say Covid measures are physically and mentally harmful to health, as well as to the social environment and the economy. The authors of the paper conducted an online research on the degree of strength of two types of fear that potentially influence the decision to travel. The research was conducted during 2020, on a total sample of 250 respondents. Confirming the reliability of the questionnaire, the obtained results were processed in the software SPSS, 23.00. Descriptive statistical analysis, and multiple regression analysis, confirmed the hypothesis that fears are present in all respondents, and that both types of fears are important in predicting and making travel decisions.
\end{abstract}

Key Words: fear, Covid-19, money, travel decision JEL classification: II, Z32

\footnotetext{
${ }^{1}$ Drago Cvijanović, PhD, Full professor, University of Kragujevac, Faculty of Hotel Managament and Tourism in Vrnjačka Banja, Vojvodjanska 5A, 36210 Vrnjačka Banja, Serbia, Phone +38163295111, drago.cvijanovic@kg.ac.rs, dvcmmv@ gmail.com

2 Tamara Gajić, PhD, Assistant professor, Novi Sad Business School, Vladimira Perića Valtera 4, Novi Sad, Serbia; South Ural State University, Institute of Sports, Tourism and Service, Chelyabinsk, Russia, tamara.gajic.1977@gmail.com
} 


\section{Introduction}

The epidemic that began at the end of 2019 continues today, but the consequences it has left are unprecedented in the history of mankind (Xiang et al., 2020). The main means of preventing the spread of the disease was physical distance and restricting the movement of people (Bond et al., 2006). It is very important to see the secondary consequences in every aspect of society, especially how a pandemic affects emotional and behavioral problems such as anxiety, fear, depression, suicide (Brooks et al., 2020a; 2020b). Some of these fears also imply changes in lifestyle habits and styles. The development of the pandemic affected all social areas of life. Unprecedented negative consequences on the tourist and catering business, as well as those influencing the entire economy are being considered.

Man has always had a kind of fear (Rüsch et al., 2008). However, the appearance of an infection of such deadly proportions literally stopped life on earth. However, although the fear of not having money has always existed, now its influence has also increased. A professor of psychiatry at the University of British Columbia, Stephen Taylor, claims that maybe 10 to 15 percent of people will not return their lives to normal, due to the impact of the pandemic (Ahorsu et al., 2020; Greenberg et al., 2020).

The Australian Black Dog Institute, a leading independent mental health research organization, also expressed concern about "a significant minority who will remain affected by long-term anxiety". Fear has two components: one is based on facts and the other is psychological (Orcutt et al., 2005).There is also a fear of a lack of funds among people, and with the advent of the pandemics, and the marked decline in economic development, this fear has intensified among the people (Deci \& Ryan, 2000; Kashdan \& Rottenberg 2010).

The overall tourism business is declining sharply. Everywhere in the world, including Serbia, the drop in tourist traffic is over $60 \%$, while in Serbia as much as $90 \%$ of foreign tourists have canceled their arrival. This branch of the economy has been growing since 2013, when 6.6 million overnight stays were recorded, but the growth has accelerated since 2017. Out of 3.09 million arrivals and 8.33 million overnight stays in Serbia in 2017, a record 2019 was reached in just two years, with 3.69 million arrivals (half domestic guests, half foreign) and 10.1 million overnight stays (about six 
million domestic and four million foreign tourists) (Cvijanović \& Gajić, 2020a; Gajić et al., 2018a).

During 2020, the authors conducted an online survey on a total sample of 250 respondents, in order to determine the existence of both types of fears, their strength, and to determine which of the fears may have more influence on the decision to travel. After determining the reliability of the test, data processing was performed in the software SPSS, 23.00, and multiple regression analysis determined whether these two types of fear can be a predictor of future travel decisions.

The paper is of great importance, primarily due to the very small number of studies on similar topics. On the other hand, the research can determine the key factors and the strength of causing fear in people, predict how a pandemics can affect the entire social and economic system in the coming period, and determine measures to prevent the general collapse of certain industries in advance. The contribution of research is reflected in the affirmation of scientists and theorists, in the application of research results to future research, consumer behavior, and the business of tourism and hospitality companies.

\section{Literature review}

The global SARS epidemic of 2003 is linked to a 30 percent increase in suicides among the population over the age of 65. Measures of physical distance and confinement negatively affect people's mental health (Yilmaz et al., 2017; Ekşi et al., 2018). Job losses and financial difficulties during the global economic crisis are associated with a long-term decline in mental health (Doğan, 2015). The consequences of Covid 19 on social and economic life have not yet been statistically measured, but they are certainly very noticeable. Fear is a normal state in humans and it is realistically present in threatening situations. However, not so rarely the feeling of fear with all physical and mental manifestations is not in adequate correlation with the degree of threat, which is sometimes completely absent, when we talk about irrational fear or anxiety (Cribb et al., 2006; Aydın, 2020; Seçer \& Ulaş, 2020). So, as fear is an appropriate response to real danger, anxiety is an inadequate response to unreal danger.

The problem here is more physical and social isolation and the severance of contacts, and thus lifestyles, so in that context we only need to redistribute life priorities (Machell et al., 2015; Xiang et al., 2020). The 
most important thing is to maintain a routine, with planned daily activities - stay in touch with close friends, think about things we never had time for, use the time to rethink some of our feelings (Garcia, 2017). People react differently to conditions of confinement and distance, through shock, panic, acute stress, sadness, anxiety disorder and depression. The tourism industry is in dire need of new steps and new words from its leaders (Gajić et al., 2017). At this moment of relative stagnation, as difficult as it is, the passenger industry can be reset and grow again while at the same time building greater resilience (Wang et al., 2002; Banerjee et al., 2020).

Due to fear and loss, many travel leaders, including destination vendors, continue to look for a better way forward (Gajić et al., 2018b). Destinations facing an economic emergency do their best to mitigate damage to businesses and livelihoods. Yet, as the health crisis prevails, more destination vendors are thinking about how to change tourism because they know it needs to, be it pandemics or not (Doğan, 2015; Yilmaz et al., 2017). On the other hand, the psychological component of fear can lead to sacrifice (Mahaffey et al., 2013).

In some cases, there are concerns of residents about excessive tourism or mass tourism, as well as mass gatherings in restaurants in many places around the world. People blame tourism for many things that go wrong, even when there is no direct connection. COVID-19 has made one thing clear: there is no point in going back to normal work and old habits. In many places, the old ways of doing business are already lost. Too many marketing professionals seem to freeze in fear and wait for all their actors, politicians or industry to show up (Park \& Park, 2020; Shigemura et al., 2020).

This is a perfect example of circular reasoning: refusing to do something new until everyone agrees that it works, even though no one can know that a new thing will succeed until they try it (Peardon, 2015). Some people are afraid of transforming tourism, because it means losing the perception of business stability as usual (Berking et al., 2009).

At the beginning of 2020, it seemed that the tourist record in Serbia would easily break the record: in February 2020, about 730,000 overnight stays were recorded, almost as many as there were in 2019 in April $(776,000)$ (Cvijanović \& Gajić, 2020b; Gajić et al., 2020). But February marked the end of the fairy tale and the beginning of a nightmare in tourism - both domestically and globally - and there is still no indication of when that 
nightmare will pass. According to the forecasts of the World Tourism Organization (UNWTO), international tourism could fall by between 60 and 80 percent compared to last year. The Corona-19 pandemics is the worst crisis that international tourism has faced since the first results were recorded (1950), the UNWTO estimates (Park \& Park, 2020).

The worst affected are Asia and the Pacific region with 33 million fewer tourist arrivals. Right behind is Europe. If the mildest scenario is realized (a drop of 60 percent), i.e. should the international borders be opened and travel easier from July, that would mean that the losses in tourism will be around 910 billion dollars, the UNWTO estimates. If the restrictions lasted until December, the decline would be around 80 percent, with losses of 1.2 billion dollars. The Germans conducted a similar study in 2020, where, after analyzing the data, they came to the conclusion that the fear of lack of money or economic fear is stronger than the fear of pandemics (Satici et al., 2020).

Similar to their research, and taking a smaller number of questions in the questionnaire, only three, the authors of the paper came to a completely different result by researching a sample of 250 online participants. Namely, the results that have been obtained unequivocally confirm that the fear of infection on the journey is much stronger than the economic fear or the fear of lack of funds due to the crisis caused by the pandemics. The research is one of the first conducted in Serbia, and will be of great importance for future research on this issue, and the creation of a comparative analysis with other countries.

\section{Methodology}

The paper uses the method of collecting and studying the available literature, its analysis and systematization, all with the aim of showing the justification and usefulness of the selected statistical model of measurement. The paper will be based on the application of: inductive and deductive methods of inference, data analysis method (descriptive measures and frequency, percentage measures), statistical analysis method, multiple regression analysis. The research was done through an online panel, EMS research (Electronic Mail Survey). There are several ways to set up online surveys, and the authors opted for Google docs, because this service is increasingly in use and its use is already implied. 
The authors analyzed 250 completed questionnaires, and the questionnaire contained three demographic variables and three questions to be answered. Multiple linear regression was used to determine as many factors (independent variables) as possible that affect the dependent variable.

The basic assumptions for predicting the value of a dependent variable based on the value of independent variables are met. if all the preconditions are met. The magnitude of the regression coefficient tells what the relative influence of each independent variable is. The existence of a linear relationship between variables is a prerequisite for the use of regression analysis. When determining the statistical significance of the obtained results, the level of risk probability of $5 \%$ was taken.

The authors proceeded to the hypotheses:

H1: The fear of infection is stronger than the fear of lack of money.

H2: Based on the fear of infection and the fear of lack of money, the result on the criterion variable - making a travel decision cannot be predicted. H2a: Based on the fear of infection and the fear of lack of money, the result can be predicted on the criterion variable - making a travel decision.

\section{Results and discussion}

The obtained categorical variables are presented as follows: absolute (f) and relative $(\%)$ frequency. The arithmetic mean shows the central tendency of numerical variables, and the deviations are given by standard deviation (st.dev). The frequency distribution of numerical characteristics was examined by indicators of distortion and courtesy.

Methods of parametric statistics were used, because it was determined that all variables are normally distributed. The selected significance level is 0.05 (at the significance level). The results are shown in a Table 1. Generally speaking, the instrument shows satisfactory measuring characteristics. Reliability was determined by the Crombach alpha coefficient. The internal reliability of the questionnaire used is 0.80 (Krombach's alpha coefficient $\alpha=0.866$, with standardization $\alpha=0.862$ ).

About 148 men and 102 women participated in the research. Regarding the age category, a total of 42 respondents belong to the category of 18-30 years, followed by 134 respondents in the range of 31-60 years of age, and 74 respondents above the age limit of 61 years. Looking at the educational demographic structure, it is apparent that there are three respondents with 
primary school education, 96 of them with secondary education, 107 with university education, and 44 with postgraduate education.

Table 1: Descriptive values of given research dimensions

\begin{tabular}{|c|c|c|c|c|c|c|c|c|}
\hline \multirow{2}{*}{ Dimension } & \multicolumn{5}{|c|}{ Frequency and percentage values } & \multicolumn{2}{c|}{ Descriptive } \\
\cline { 2 - 9 } & \multicolumn{3}{|c|}{ Yes } & \multicolumn{2}{c|}{ No } & \multicolumn{2}{c|}{ Partially } & \multicolumn{2}{c|}{ values } \\
\cline { 2 - 9 } & frequency & $\%$ & frequency & $\%$ & frequency & $\%$ & m & sd \\
\hline $\begin{array}{c}\text { Fear of } \\
\text { infection }\end{array}$ & 183 & $73.2 \%$ & 40 & $16 \%$ & 27 & $10.8 \%$ & 1.38 & 0.673 \\
\hline $\begin{array}{c}\text { Fear of lack } \\
\text { of money }\end{array}$ & 128 & $51,2 \%$ & 61 & $24.4 \%$ & 61 & $24.4 \%$ & 1.73 & 0.829 \\
\hline $\begin{array}{c}\text { Travel } \\
\text { decision }\end{array}$ & 90 & $36 \%$ & 56 & $22 \%$ & 104 & $41.6 \%$ & 2.06 & 0.881 \\
\hline
\end{tabular}

Source: Author's research

Table 1. provides insight into descriptive statistical values. That the fear of infection affects people much more is shown by the data that 183 of them (73.25) answered yes $(\mathrm{m}=1.38$; $\mathrm{sd}=0.637)$. A total of 40 respondents said they had no fear of infection on the trip, and 27 respondents were hesitant in this response. About 51.2\% (128) of the study participants stated that they were afraid of lack of money if they decided to go on the road at this time while the pandemic was $(\mathrm{m}=1.73$; $\mathrm{sd}=0.829)$. A total of 61 research participants deny this type of fear, and the same number are undecided on the issue. Whether fear influences the decision to travel, 90 respondents confirmed, 56 denied, and 104 were indeterminate $(\mathrm{m}=2.06 ; 0.881)$.

Multiple regression analysis determined whether the two types of fears predict a score on the criterion variable of the decision on future tourist travel.

Table 2: Model Summary

\begin{tabular}{|c|c|c|c|c|}
\hline Model & $\mathrm{R}$ & $\mathrm{R}$ Square & Adjusted R Square & Std. Error of the Estimate \\
\hline 1 & $0.238^{\mathrm{a}}$ & 0.057 & 0.049 & 0.859 \\
\hline \multicolumn{5}{|c|}{ a. Predictors: (Constant), fear of infection, fear of lack of money } \\
\hline
\end{tabular}

Source: Author's research

Table 2. shows the value of $\mathrm{R} 2$, which shows what percentage of variance is explained in the sample, and Adjusted R2 Square, which shows how many percent of variance is explained in the population.

Table 3. shows the results of the new test, and the statistical significance, which was achieved in this case, because the value of $p=0.001$. 
Table 3: ANOVA ${ }^{a}$

\begin{tabular}{|c|c|c|c|c|c|c|}
\hline \multicolumn{2}{|c|}{ Model } & $\begin{array}{c}\text { Sum of } \\
\text { Squares }\end{array}$ & df & $\begin{array}{l}\text { Mean } \\
\text { Square }\end{array}$ & $\mathrm{F}$ & Sig. \\
\hline \multirow{3}{*}{1} & Regression & 10.33 & 2 & 5.467 & 7.408 & $.001^{\mathrm{b}}$ \\
\hline & Residual & 182.283 & 247 & 0.738 & & \\
\hline & Total & 193.216 & 249 & & & \\
\hline
\end{tabular}

Source: Author's research

Table 4: Coefficients ${ }^{a}$

\begin{tabular}{|c|c|c|c|c|c|}
\hline \multirow[t]{2}{*}{ Model } & \multicolumn{2}{|c|}{$\begin{array}{l}\text { Unstandardized } \\
\text { Coefficients }\end{array}$} & $\begin{array}{l}\text { Standardized } \\
\text { Coefficients }\end{array}$ & \multirow[t]{2}{*}{ t } & \multirow[t]{2}{*}{ Sig. } \\
\hline & $\mathrm{B}$ & Std. Error & Beta & & \\
\hline (Constant) & 1.40 & 0.173 & & 11.200 & 0.00 \\
\hline Fear of infection & 0.253 & 0.081 & 0.194 & 3.125 & 0.00 \\
\hline $\begin{array}{c}\text { Fear of lack of } \\
\text { money }\end{array}$ & 0.135 & 0.066 & 0.127 & 2.044 & 0.04 \\
\hline
\end{tabular}

Source: Author's research

When the statistical significance is proven, we move on to perceiving the significance of the predictor, which is the goal of this model. Based on the above data, it was determined that this model fits the data: Adjusted R2 Square $=49, \mathrm{~F}(2.247)=7.408, \mathrm{P}=0.001$.

Table 4 shows how much each of the fears individually contributes to the score of the criterion variable or the decision to travel, where $b$ is the standardized partial contribution that tells whether that predictor is significant in itself and how strong it is. However, $\beta$ is calculated as a correlation of exactly how much the predictor is related to the criterion variable (travel decision making). The model explains $49 \%$ of the total variance. The criterion variable Travel decision is predicted by a significant fear of infection on the road $(b=0.253 ; \beta=0.194, p=0.00)$. Then, the fear of a lack of sheep also predicts the outcome of the travel decision, but to a lesser extent than the fear of infection $(b=0.125, \beta=0.127, p=0.04)$. Based on the obtained results, the hypotheses were confirmed that there are pronounced fears among the respondents, where the fear of infection is 
stronger than the fear of lack of money. Then, the alternative H2a hypothesis that fear of infection and fear of lack of money significantly predict a score on a criterion variable or a travel decision.

A study conducted in Germany in September 2020 shows that true fear of the virus is present in a very small number of respondents. The so-called fear index has dropped from 39 to 37, which is the lowest since the survey has been conducted since the early 1990s. About 2,400 people answered questions about the biggest fears regarding the economic and political situation and personal life. About $32 \%$ of them are afraid of the Crown infection, but $53 \%$ of the participants in the research are afraid of Trump's policy. Economic worries and job losses are still at the very top of the fears ladder. Fifty percent of respondents expressed fear of rising living costs (Aydın, 2020).

\section{Conclusion}

The pandemic of COVID-19 disease caused by the new coronavirus SARSCoV-2 quickly became a global and multidimensional problem. The fear of infection, social distancing, economic problems, cessation of normal daily functioning, and pervasive uncertainty are just some of the factors that affect mental health in the short and long term (Ahorsu et al., 2020).

The COVID-19 pandemic is a new and hitherto unknown danger, thus fear is a natural and expected occurrence. Fear is in the function of raising the level of vigilance and attention in order to adequately face danger and survive (Park \& Park, 2020). Fear is instinct, and behavior is automatic and often irrational. In any case, the fact is that the COVID-19 disease pandemic is a serious and global threat with a high risk of infection. However, the dimension of fear, in addition to the actual risk, also depends on the perceived risk, i.e. personal experience of danger (Xiang et al., 2020; Gajić et al., 2019).

For people who are anxious by nature and find it difficult to cope with stressful situations or whose adjustment mechanisms are exhausted, this risk has another dimension (Bond et al., 2006). Then we turn to the environment and the authorities, from whom we expect a solution and protection. Being prone to phobias means having an incredible fear of certain things, situations or activities, and that is exactly how phobias differ from everyday stress or worry (Ornell et al., 2020). Some people feel 
anxious and under stress in certain situations, e.g. when they speak in front of a large number of people and the like (Kashdan \& Rottenberg, 2010).

When it comes to people who are prone to phobias, all this is much more extreme and goes to the extent that people have a lot of difficulties with performing even everyday life activities like going to work, taking the elevator. People who have certain phobias are under constant stress. is conditioned by the fact that they are too close to the object that disturbs them, in disturbing situations or engage in activity that triggers fear in them (Deci \& Ryan, 2000). The fear of being infected with the new virus also caused the economy to decline, and reduced tourist needs. Many have canceled their trips, either because of restrictive measures or fear of infection. However, there are also people who have accused the tourism and hospitality industry as the biggest culprit for the spread of the infection.

One of the fears that also greatly influences human decisions is the fear of lack of money. The latest research in Germany showed that people have more economic fear than fear of infection. Only 32 percent (as opposed to 35 percent last year) fear a serious illness. Only one in three respondents fears that he or someone from the immediate environment will be infected with the corona virus (Aydin, 2020).

A study conducted by the public service ARD at the beginning of the month came to similar results. Only $42 \%$ believe that pandemics of this magnitude could continue in the future due to globalization. Remstedt says that it surprised them, and that the Germans today are more worried about the loss of welfare than the infection (Aydın, 2020).

The authors of the paper conducted an online survey, on a total sample of 250 respondents, during 2020. The aim of the research was to determine which fear causes greater negative consequences in people, and whether both fears can influence the prediction of travel decisions. The results obtained by descriptive statistical analysis showed that the fear of infection is stronger than the fear of lack of money.

By multiple regression analysis, it was found that the fear of infection more strongly predicts the score on the criterion variable travel decisions $(\mathrm{b}=$ $0.253 ; \beta=0.194, p=0.00$ ). However, the fear of lack of money can also be a predictor of the outcome of the decision to travel $(b=0.125, \beta=0.127$, $p=0.04)$. The hypotheses of the research have been confirmed. The impact of the fear of infection on the road is stronger than the lack of money. Also, 
the research can serve as part of a broader global study at the global level, because there is a small amount of research on this issue.

There have been epidemics before, but there have never been such drastic measures. This creates a fertile ground for spreading fears. The longer citizens are forced to give up their usual daily routine, the more the fear grows (Machell et al., 2015).

The time in which we live, along with the new corona virus, has brought with it many challenges and doubts and forced us to adapt our daily lives to different patterns of behavior. The corona virus pandemic has endangered the tourist industry around the world, completely disrupting all types of traffic and border passability. Many have decided to go on vacation in Serbia itself (Cvijanović \& Gajić, 2020b). However, there are problems here as well. Limited number of visitors, closed restaurants, limited working hours, closed bases. But those interested in vacationing within the borders of Serbia will encounter two problems that are seemingly in complete contrast - the lack of accommodation and high prices.

In May 2020, the total number of tourist arrivals decreased by 87.6 percent compared to May 2019, and when it comes to foreign tourists, this is a decline of 97.8 percent. The current overbooking, caused by the impossibility of summer vacations outside Serbia, in a way represents a continuation of the trend of popularity of rural tourism in the last few years. The average consumption of a foreign guest in Belgrade for gastronomic services, souvenirs and entertainment, nightclubs and discos is around 69 euros (Cvijanović \& Gajić, 2020b). If we add traffic, and that is about 20 percent of the value of overnight stays, ie another 26 million euros, if we add events, weddings, the congress industry, that is another twenty million euros, we are approaching the figure of 300 million euros. Serbia lost so much from tourists this year in the period from March 15 to June 1. In hotels alone, there are 2,130,000 fewer overnight stays in that period, a total of 3.8 to 4 million overnight stays, including private accommodation.

Speaking about capacities, during 2018 and 2019, more than 30 hotels were opened in Serbia and the construction of new ones for 2020 has been announced (Gajić et al., 2020). The fact is that the attractiveness of Serbia for investors will increase after the pandemic, given the demand for specific tourism products that may be missing for now. According to data from HORES, Belgrade is richer by 12 hotels from 2018, and there are a total of 380 categorized hotels in Serbia (Gajić et al., 2020). 


\section{Acknowledgements}

The paper is part of the research at the project III-46006 "Sustainable agriculture and rural development in terms of the Republic of Serbia strategic goals realization within the Danube region", financed by the Ministry of Education, Science and Technological Development of the Republic of Serbia.

\section{References}

1. Ahorsu, D. K., Lin, C. Y., Imani, V., Saffari, M., Griffiths, M. D., Pakpour, A. H. (2020). The fear of COVID-19 scale: development and initial validation. International journal of mental health and addiction, Vol. 27, 1-9.

2. Aydin, E. (2020). Effect of Perfectionism, Social Competence and Psychological Well-Being on Physical Activity of Students. African Educational Research Journal, Vol. 8, No. 1, 90-95.

3. Banerjee, D. (2020). The other side of COVID-19: impact on obsessive compulsive disorder (OCD) and hoarding. Psychiatry research, Vol. 288, 112966.

4. Berking, M., Neacsiu, A., Comtois, K. A., Linehan, M. M. (2009). The impact of experiential avoidance on the reduction of depression in treatment for borderline personality disorder. Behaviour research and therapy, Vol. 47, No. 8, 663-670.

5. Bond, F. W., Hayes, S. C., Barnes-Holmes, D. (2006). Psychological flexibility, ACT, and organizational behavior. Journal of Organizational Behavior Management, Vol. 26, 25-54.

6. Brooks, S. K., Amlôt, R., Rubin, G. J., Greenberg, N. (2020a). Psychological resilience and post-traumatic growth in disaster-exposed organisations: overview of the literature, BMJ military health, Vol. 166, No. $1,52-56$.

7. Brooks, S. K., Webster, R. K., Smith, L. E., Woodland, L., Wessely, S., Greenberg, N., et al. (2020b). The psychological impact of quarantine and how to reduce it: rapid review of the evidence, Lancet, Vol. 395, No. 10227, 912-920. 
8. Cvijanović, D., Gajić, T., (2020a). Analisys of the Market Values of Lemeska Spa: Importance and Possibility of Renewal Throughthe Cluster System. Sustainable Agriculture and Rural Development in Terms of The Republic of Serbia Strategic Goals Realization Within the Danube Region - Science and practice in the service of agriculture - Thematic Proceedings. Institute of Agricultural Economics Belgrade. 177-193.

9. Cvijanović, D., Gajić, T., (2020b). Rural Resource as a Tourist Attractor. $V$ Medjunarodni skup Turizam u funkciji ruralnog razvoja Republike Srbije, 4-6 jun, Vrnjacka Banja.

10. Cribb, G., Moulds, M. L., Carter, S. (2006). Rumination and experiential avoidance in depression, Behaviour Change, Vol. 23, No. 3, $165-176$.

11. Deci, E. L., Ryan, R. M. (2000). The "what" and "why" of goal pursuits: human needs and the self-determination of behavior, Psychological inquiry, Vol. 11, No. 4, 227-268.

12. Doğan, T. (2015). Kısa psikolojik sağlamlık ölçeği'nin Türkçe uyarlaması: Geçerlik ve güvenirlik çalışması. The Journal of Happiness \& Well-Being, Vol. 3, No. 1, 93-102.

13. Ekşi, H., Kaya, Ç, Kuşcu, B. (2018). Multıdımensıonal experıentıal avoidance questionnaire-30: adaptation and psychometric properties of the Turkısh version, Annual Congress: ICRE. 483-487.

14. Gajić, T., Petrović, M.D., Radovanović, M., Tretiakova, T.N., Syromiatnikov, J.A. (2020). Possibilities of Turning Passive Rural Areas into Tourist Attractions Through Attained Service Quality. European Countryside Journal, Vol. 12, No. 2, 179-276.

15. Gajić, T., Vujko, A., Tretiakova, T.N., Petrovic, D.M., Radovanovic, M., Vukovic, D. (2019). Evaluation of Service Quality Based on Rural Households Visitors - Serbian Case Study. The Central European Journal of Regional Development and Toursm, Vol. 11, No. 2, 4-20.

16. Gajić, T., Penić, M., Vujko, A.,Petrović, M.D., (2018a). Development Perspectives of Rural Tourism Policy - Comparative Study of Rural Tourism Competitiveness Based on Perceptions of Tourism Workers in Slovenia and Serbia, Eastern European Countryside, Vol. 24, No. 1, 144-154. 
17. Gajić,T., Vujko, A., Petrović, M.D., Mrkša, M., Penić, M. (2018b). Examination of regional disparity in the level of tourist offer in rural clusters of Serbia. Economic of agriculture, Vol.65, No. 3, 911-929.

18. Gajić,T., Vujko, A., Penić, M., Petrović, M. Mrkša, M. (2017): Significant involvement of agricultural holdings in rural tourism development in Serbia. Economic of agriculture, Vol. 64, No. 3, 901-919.

19. Garcia, R. (2017). Neurobiology of fear and specific phobias. Learning \& Memory. Vol. 24, No. 9, 462-471.

20. Greenberg, N., Docherty, M., Gnanapragasam, S., Wessely, S. (2020). Managing mental health challenges faced by healthcare workers during covid-19 pandemic. BMJ.

21. Kashdan, T. B., Rottenberg, J. (2010). Psychological flexibility as a fundamental aspect of health. Clinical psychology review, Vol. 30, No. 7, 865-878.

22. Machell, K. A., Goodman, F. R., Kashdan, T. B. (2015). Experiential avoidance and well-being: A daily diary analysis. Cognition and Emotion, Vol. 29, No. 2, 351-359.

23. Mahaffey, B. L., Wheaton, M. G., Fabricant, L. E., Berman, N. C., Abramowitz, J. S. (2013). The contribution of experiential avoidance and social cognitions in the prediction of social anxiety, Behavioural and cognitive psychotherapy, Vol. 41, No. 1, 52-65.

24. Orcutt, H. K., Pickett, S., Pope, E. (2005). Experiential avoidance and forgiveness as mediators in the relation between traumatic life events and PTSD symptoms. Journal of Social and Clinical Psychology, Vol. 24, No. 7, 1003-1029.

25. Ornell, F., Schuch, J. B., Sordi, A. O., Kessler, F. H. P. (2020). "Pandemic fear" and COVID-19: mental health burden and strategies. Brazilian Journal of Psychiatry, Vol. 42, No. 3, 232-235.

26. Park, S. C., Park, Y. C. (2020). Mental health care measures in response to the 2019 novel coronavirus outbreak in Korea. Psychiatry investigation, Vol. 17, No. 2, 85-86. 
27. Peardon, S. (2015). Ebola's mental-health wounds linger in Africa, Nature News, Vol. 519, No. 7541, 13-15.

28. Rüsch, N., Schiel, S., Corrigan, P. W., Leihener, F., Jacob, G. A., Olschewski, M. (2008). Predictors of dropout from inpatient dialectical behavior therpay among women with borderline personality disorder. Journal of Behavior Therapy and Experimental Psychiatry, Vol. 39, No. 4, 497-503.

29. Satici, B., Gocet-Tekin, E., Deniz, M. E., Satici, S. A. (2020). Adaptation of the Fear of COVID-19 Scale: its association with psychological distress and life satisfaction in Turkey. International Journal of Mental Health and Addiction, 1-9.

30. Seçer, İ, Ulaş, S. (2020). An Investigation of the Effect of COVID-19 on OCD in Youth in the Context of Emotional Reactivity, Experiential Avoidance, Depression and Anxiety. International Journal of Mental Health and Addiction, Vol. 13, 1-14.

31. Shigemura, J., Ursano, R. J., Morganstein, J. C., Kurosawa, M., Benedek, D. M. (2020). Public responses to the novel 2019 coronavirus (2019-nCoV) in Japan: Mental health consequences and target populations. Psychiatry and clinical neurosciences, Vol. 74, No. 4, 281-282.

32. Wang, C., Pan, R., Wan, X., Tan, Y., Xu, L., Ho, C. S., Ho, R. C. (2020). Immediate psychological responses and associated factors during the initial stage of the 2019 coronavirus disease (COVID-19) epidemic among the general population in China. International journal of environmental research and public health, Vol. 17, No. 5, 1729.

33. Xiang, Y. T., Yang, Y., Li, W., Zhang, L., Zhang, Q., Cheung, T., Ng, C. H. (2020). Timely mental health care for the 2019 novel coronavirus outbreak is urgently needed. The Lancet Psychiatry, Vol. 7, No. 3, 228229.

34. Yilmaz, O., Boz, H., Arslan, A. (2017). The validity and reliability of depression stress and anxiety scale (DASS 21) Turkish short form. Research of Financial Economic and Social Studies, Vol. 2, No. 2, 78-91. 